\title{
Characterization of a Labrys sp. strain Wy1 able to utilize 2,2-dichloropropionate (2,2-DCP) as sole source of carbon
}

\author{
Wen-Yong Wong ${ }^{1}$ and Fahrul Huyop ${ }^{2 *}$ \\ ${ }^{1}$ Microbiology Laboratory, Faculty of Biosciences and Bioengineering, Universiti Teknologi Malaysia, 81310 Skudai, \\ Johor, Malaysia. \\ ${ }^{2}$ Industrial Biotechnology Department, Faculty of Biosciences and Bioengineering, Universiti Teknologi Malaysia, \\ 81310 Skudai, Johor, Malaysia. \\ Accepted 23 August, 2011
}

Industrial chemicals and pesticides from agricultural activities cause a considerable threat to the environment. 2,2-dichloropropionate (2,2-DCP) is a synthetic halogenated compound used as herbicide. High concentration of 2,2-DCP is toxic if released to the environment and may pollute the soil and ground water source. Using current enrichment technique it was expected to isolate a new bacteria species able to degrade $\alpha$-halocarboxylic acid. Strain Wy1 isolated from soil in Melaka rubber estate was able to utilize $30 \mathrm{mM}$ 2,2-DCP as the sole source of carbon and energy with maximum chloride ion released of $0.27 \mathrm{mmol} / \mathrm{L}$ in the liquid growth medium. The biochemical test and 16S rRNA analysis suggested that the bacterial identity was from the genus Labrys sp., and therefore it was designated as Labrys sp. strain Wy1. The cells doubling time in $30 \mathrm{mM}$ 2,2-DCP liquid minimal medium was $33.44 \mathrm{~h}$. Cell growth was inhibited when grown in liquid minimal medium above $30 \mathrm{mM}$ 2,2-DCP due to the toxicity of 2,2-DCP to the cells. This is the first reported case that the genus Labrys sp. is able to degrade 2,2-DCP.

Key words: 2,2-dichloropropionate, dehalogenase, soil bacteria, Labrys sp.

\section{INTRODUCTION}

Halogenated compounds were used extensively as herbicide and as intermediate chemicals in many industries. Due to the complexity, toxicity, persistence and ubiquitous distribution spreading of these xenobiotic compounds, they have threatened the health and living quality of human and other organisms (Fetzner and Lingens, 1994). Degradation of halogenated compound has been reported since the earlier of 20th century by Penfold (1913).

2,2-dichloropropionate (2,2-DCP)- or Dalapon is an odourless and colourless herbicide used to control and regulate the growth of certain weeds, such as quick

${ }^{*}$ Corresponding author. E-mail: fzhutm@gmail.com. Tel: +60 12 684 9374. Fax: +607553 4556. grass, Bermuda grass and cattails. It is an effective inhibitor of panothenic acid production (Prasad and Blackman, 1965) and pyruvate utilization in bacteria (Redemann and Meikle, 1955). Degradation of herbicide Dalapon was reported earlier by Magee and Colmer (1959) after observation of bacteria that produce dehalogenase enzyme. Since then, studies on isolation of microbes that potentially produce dehalogenases have been undertaken (Jing and Huyop, 2007; 2008; Schwarze et al., 1997; Weightman et al., 1982; Motosugi et al., 1982; Allison et al., 1982; Hardman and Slater, 1981).

The enzymes which were responsible for the degradation of halogenated compound were dehalogenases, discovered and named by Jensen (1957). Culturing and enrichment of microorganism that can produce dehalogenase in the presence of halogenated compound 
in the environment was the most favorable method. Several dehalogenase producing bacteria were isolated using this technique including were Methylobacterium sp. HJ1 (Jing and Huyop, 2008), Pseudomonas putida PP3 (Senior et al., 1976), Xanthobacter autotrophicus GJ10 (Janssen et al., 1985), Pseudomonas B6P (Mesri et al., 2009) and Rhizobium sp. (Berry et al., 1979). Current research also incorporated the methods as described by previous work to increase the probability of isolating reliable bacteria. Therefore, the aim of this study is to isolate and characterize bacteria from Melaka rubber estate agricultural soil which able to utilize 2,2-DCP as only carbon source. Various types of chlorinated pesticides and herbicides were used by the estate owner and we were interested to isolate and characterize the bacteria resistant to chlorinated xenobiotics from the soil.

\section{MATERIALS AND METHODS}

\section{Growth media preparation}

Routinely, cells were grown in PJC chloride-free minimal media. Stock solution was prepared as $10 \mathrm{x}$ concentration of basal salts containing $\mathrm{K}_{2} \mathrm{HPO}_{4} .3 \mathrm{H}_{2} \mathrm{O}(42.5 \mathrm{~g} / \mathrm{l}), \mathrm{NaH}_{2} \mathrm{PO}_{4} .2 \mathrm{H}_{2} \mathrm{O}(10.0 \mathrm{~g} / \mathrm{l})$ and $\left(\mathrm{NH}_{4}\right)_{2} \mathrm{SO}_{4}(25.0 \mathrm{~g} / \mathrm{l})$. The trace metal salts solution was a $10 \mathrm{x}$ concentrated stock that contained nitriloacetic acid $\mathrm{C}_{6} \mathrm{H}_{9} \mathrm{NO}_{6}(1.0$ $\mathrm{g} / \mathrm{l}), \mathrm{MgSO}_{4}(2.0 \mathrm{~g} / \mathrm{l}), \mathrm{FeSO}_{4} .7 \mathrm{H}_{2} \mathrm{O}(120.0 \mathrm{mg} / \mathrm{l}), \mathrm{MnSO}_{4} .4 \mathrm{H}_{2} \mathrm{O}(30.0$ $\mathrm{mg} / \mathrm{l}), \mathrm{ZnSO}_{4} \cdot \mathrm{H}_{2} \mathrm{O}(30 \mathrm{mg} / \mathrm{l})$ and $\mathrm{CoCl}_{2} \cdot 6 \mathrm{H}_{2} \mathrm{O}(10 \mathrm{mg} / \mathrm{l})$ in distilled water (Hareland et al., 1975). Minimal media for growing bacteria contained $10 \mathrm{ml}$ of $10 \mathrm{x}$ basal salts and $10 \mathrm{ml}$ of $10 \times$ trace metal salts per $100 \mathrm{ml}$ of distilled water and were autoclaved $\left(121^{\circ} \mathrm{C}\right.$, for $15 \mathrm{~min}$ at $15 \mathrm{psi}$ ). Carbon sources (1 M, 2, 2-dichloropropionate) was sterilised separately and added aseptically to the media to the desired final concentration. In order to prepare solid medium, Oxoid bacteriological agar $(1.5 \% \mathrm{w} / \mathrm{v})$ was added prior to sterilisation. Samples were removed periodically and the growth was determined by measuring turbidity at $A_{600 n m}$ and chloride ion liberation at $A_{460 n m}$ (Bergman and Sanik, 1957).

\section{Sample preparation}

Soil sample $(5 \mathrm{~g})$ from rubber plantation estate in state of Melaka was mixed together in minimal medium containing $10 \mathrm{mM}$ of 2,2DCP and incubated in orbital shaker at $30^{\circ} \mathrm{C}$. Bacterial growth was monitored at appropriate time interval. For the isolation of pure colonies, $0.1 \mathrm{~mL}$ of aliquot was spread onto solid minimal media contained $10 \mathrm{mM}$ 2,2-DCP. For cells purification, colonies were selected and subcultured onto fresh plates containing similar amount of 2,2-DCP as carbon source. Plates were incubated at $30^{\circ} \mathrm{C}$.

\section{Biochemical test}

A variety of biochemical tests were carried out including oxidase test, catalase test, gelatine liquefaction test, lactose utilization test, Simmons citrate test, indole test, nitrate reduction test, urease test, triple sugar iron (TSI) test and oxidation fermentation (OF) test to characterize bacteria's biochemical properties. All test media were incubated at temperature ranging from 30 to $35^{\circ} \mathrm{C}$ separately to observe their optimum bacterial activity.

\section{S rRNA gene analysis}

Genomic DNA from bacterial culture was isolated using Promega® Wizard $\AA$ Genomic DNA Purification Kit. PCR amplification of the 16S rRNA gene for bacteria identification was carried out using universal primers, FD1 (5'-aga gtttgatcctggctc ag-3') and rP1 (5'acg gtcataccttgttacgac tt-3') as suggested by Weisburg et al. (1991). Each PCR reaction mixture (total volume $50 \mu \mathrm{L}$ ) contained 1 unit/mL Taq polymerase (Promega®), $50 \mathrm{mM}$ Tris- $\mathrm{HCl}(\mathrm{pH} 9.0)$, $50 \mathrm{mM} \mathrm{NaCl}, 1.2 \mathrm{mM}$ of $\mathrm{MgCl}_{2}, 160 \mu \mathrm{M}$ of each dNTPs, $1 \mu \mathrm{mol}$ of each primer, nuclease free water and $100 \mathrm{ng}$ of DNA template. The PCR protocol consisted of a denaturing process of $94^{\circ} \mathrm{C}$ for $5 \mathrm{~min}$, followed by 30 cycles of $92^{\circ} \mathrm{C}$ for $1 \mathrm{~min}, 55^{\circ} \mathrm{C}$ for $1 \mathrm{~min}$ and $72^{\circ} \mathrm{C}$ for $2 \mathrm{~min}$, incubation at $72^{\circ} \mathrm{C}$ for $10 \mathrm{~min}$ and finally $4^{\circ} \mathrm{C}$ for infinite time for storage, using GeneAmp® PCR system 9700. Amplicons were purified using QIAGEN® QIAquick PCR purification kit and sequenced by $1^{\text {st }}$ BASE $\AA$ company (Singapore).

\section{Phylogenetic analysis}

The 16S rRNA gene sequences were compared with GenBank database using BLAST (Altschul et al., 1997) by selecting BLASTn method. Multiple sequence alignment of bacteria from different genus were constructed using profile alignment command of CLUSTAL-W from MEGA version 4 (Tamura et al., 2007). Using the same software, phylogenetic trees with bootstrap test (1000 replications) were constructed using Neighbour-Joining method (Saitou and Nei, 1987).

\section{RESULTS}

\section{Isolation and characterization of novel bacterium able to utilize 2,2-DCP}

After 4 days of incubation the colonies appeared to be white, round shape and their size ranging from 0.5-1.0 $\mathrm{mm}$ on $10 \mathrm{mM}$ 2,2-DCP minimal medium plate. Microscopic observation suggested all purified bacterial colonies were of similar type and further analysis by $16 \mathrm{~S}$ rRNA genes proved they were all clustered in the same genus and initially designated as strain Wy1.

Growth experiment was carried out (Figure 1). Minimal media supplied with $30 \mathrm{mM}$ 2,2-DCP recorded the highest growth with cells' doubling time $33.44 \mathrm{~h}$ (Table 1). However, growth was negligible in 10 and $50 \mathrm{mM}$ of 2,2DCP. Chloride ion assay showed maximum chloride ion released by bacteria grown in $30 \mathrm{mM}$ 2,2-DCP with approximately $0.27 \mathrm{mmol} / \mathrm{L}$ (Figure 2). Biochemical tests were conducted as summarised in Table 2 showed Wy1 generally matches with the most related species of Labrys Neptuniae sp. Liujia-146. 


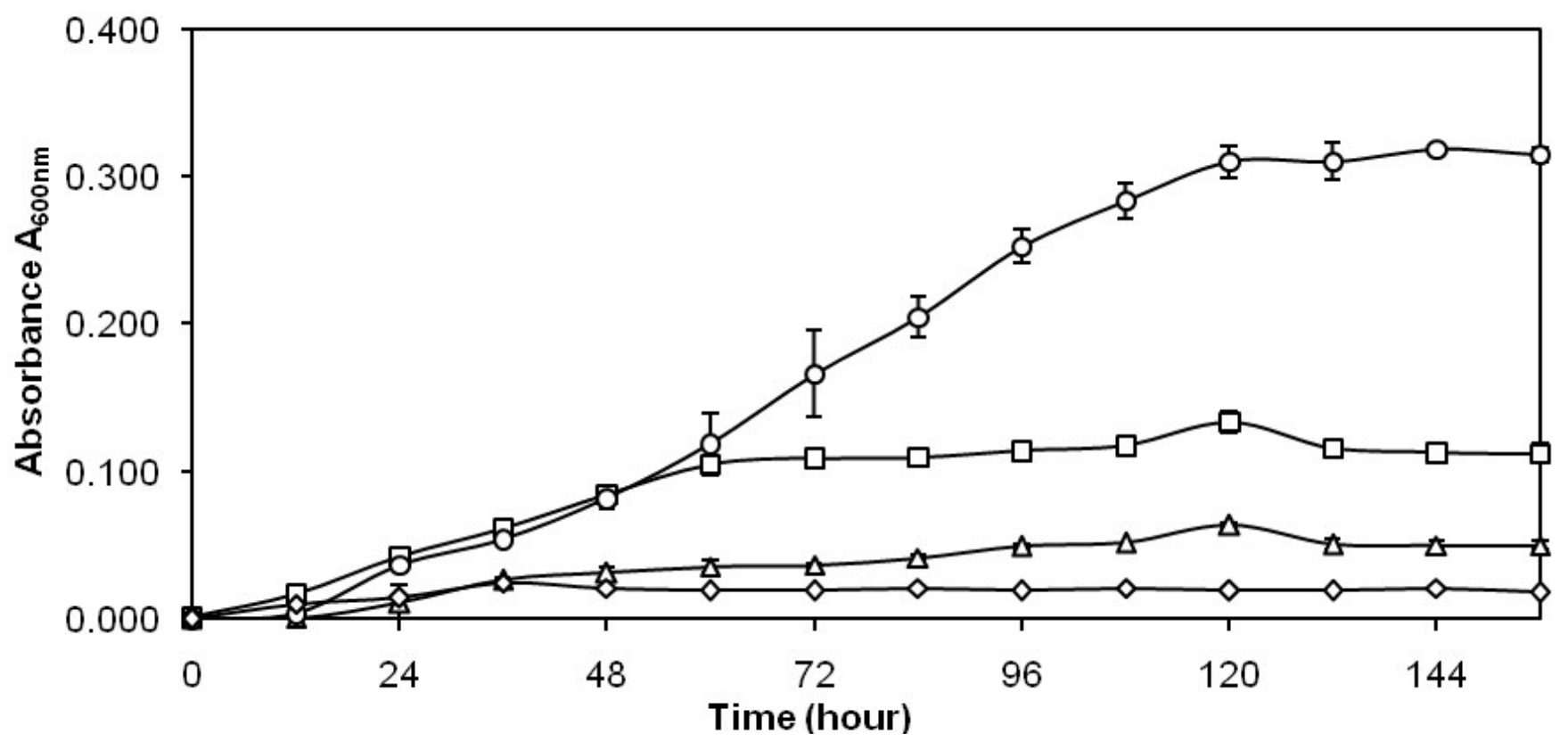

Figure 1. Growth profile of bacterium $\mathrm{Wy} 1$ in triplicate minimal media containing four different concentrations of 2,2-DCP: $10 \mathrm{mM}(\boldsymbol{\Delta}$ ), $20 \mathrm{mM}(\boldsymbol{\square}), 30 \mathrm{mM}(\mathbf{O})$ and $50 \mathrm{mM}(\diamond)$.

Table 1. Growth experiment of bacterium Wy1.

\begin{tabular}{ccc}
\hline 2,2-DCP concentration(s) (mM) & Maximum absorbance (A600nm) & Average cells' doubling time (hour) \\
\hline 10 & $0.064 \pm 0.002$ & Insignificant \\
20 & $0.134 \pm 0.007$ & 34.60 \\
30 & $0.319 \pm 0.001$ & 33.44 \\
50 & $0.025 \pm 0.002$ & Insignificant \\
\hline
\end{tabular}

\section{S rRNA gene analysis and biochemical tests and}

A total of 1351 bases of 16S rRNA gene were sequenced. BLASTn showed the isolated bacterium matched to the genus Labrys, where the first 10 species were highly identical (Table 3 ). The partial sequence of 16S rRNA gene was submitted to Gene Bank with accession number JF907580. All identical bacteria from BLASTn results were used to construct Neighbour-joining phylogenetic tree with bootstrap test. The tree shows bacteria Wy1 was grouped with Labrys neptuniae sp. Liujia-146 with the highest bootstrap value (Figure 3).

\section{DISCUSSION}

The main goal of this study is to isolate bacteria which have not been reported to utilize 2,2-DCP as sole carbon and energy source. Generally the bacterial colonies were observed after 4 to 5 days of incubation at $30^{\circ} \mathrm{C}$ with $\mathrm{pH} 7$ in aerobic condition. No colonies were observed in a blank plate contained only minimal media without adding any carbon source. Growth profile showed slow growth of bacterium $\mathrm{Wy} 1$ and the maximum absorbance only achieved approximately after 5 days in liquid culture condition (Table 1 and Figure 1). The bacteria grew best in minimal media contain $30 \mathrm{mM}$ 2,2-DCP with the highest absorbance recorded with cells doubling time of $33.44 \mathrm{~h}$. Slow growth of bacteria suggested that the inefficient of the cells uptake system of the growth substrate into the cell (Jing et al., 2010) or weak expression of the dehalogenase gene in the bacteria system. The growth of the isolated bacteria was 3 times slower compared to the previously reported Rhizobium sp. in 2,2-DCP liquid medium (Allison et al., 1982). However, detection of chloride ion released into the 


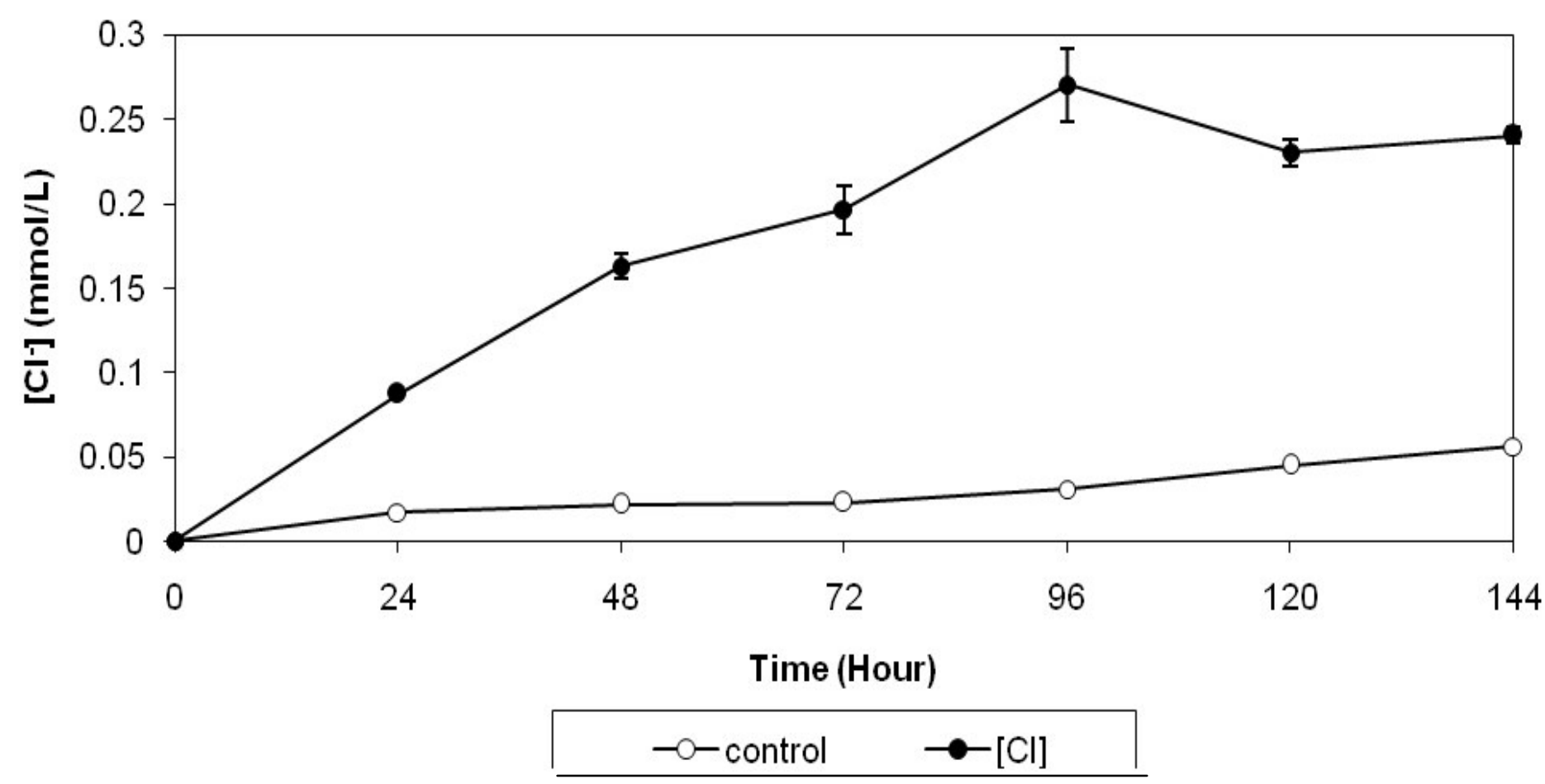

Figure 2. Chloride ion assay of Wy1 cultured in minimal media contain $30 \mathrm{mM} 2,2-\mathrm{DCP}$. Control contains minimal media with $30 \mathrm{mM} 2,2-$ DCP excluding bacteria culture.

Table 2. Comparison of biochemical test with related species.

\begin{tabular}{lccc}
\hline Test & Wy1 & Labrys neptuniae sp. Liujia-146 & Labrys methylaminiphilus sp. nov. $^{3}$ \\
\hline Lactose fermentation (MacConkey's) & + & $\mathrm{NR}^{2}$ & $\mathrm{NR}$ \\
Catalase & - & - & + \\
Oxidase & - & - & + \\
Citrate (Simmons) & - & - & + \\
Indole & - & $\mathrm{NR}$ & $\mathrm{NR}$ \\
Triple sugar ion (TSI) & - & + & + \\
Urease (Christensen's) & + & - & + \\
Oxidation fermentation (OF) of glucose & - & $\mathrm{NR}$ & - \\
Oxidation fermentation (OF) of lactose & - & - & - \\
Motility & - & - & + \\
Gelatine liquefaction & - & + & - \\
Nitrate reduction & + & & \\
\hline
\end{tabular}

"+" for positive result, "-" for negative result; NR - Not reported; Miller et al. (2005).

growth medium suggested the utilization of 2,2-DCP as a carbon source.

Figure 3 shows the taxonomic position of Wy1 with other closely related species from different family. Wy1 was clustered together with Labrys neptuniae sp. Liujia146 with high bootstrap value (98), suggesting they were closely related. However, DNA-DNA hybridization test is needed to confirm this finding and define them as same species. According to Chou et al. (2007), Labrys neptuniae sp. Liujia-146 was a budding bacteria found in root nodules of Neptunia oleracea. This is the first reported case of which Labrys sp. could survive solely on 2,2-DCP as carbon source. There has been reported case of Labrys portucalensis sp. nov. which capable of degrading fluorobenzene found in contaminated sediment from northern Portugal (Carvalho et al., 2008). Labrys 


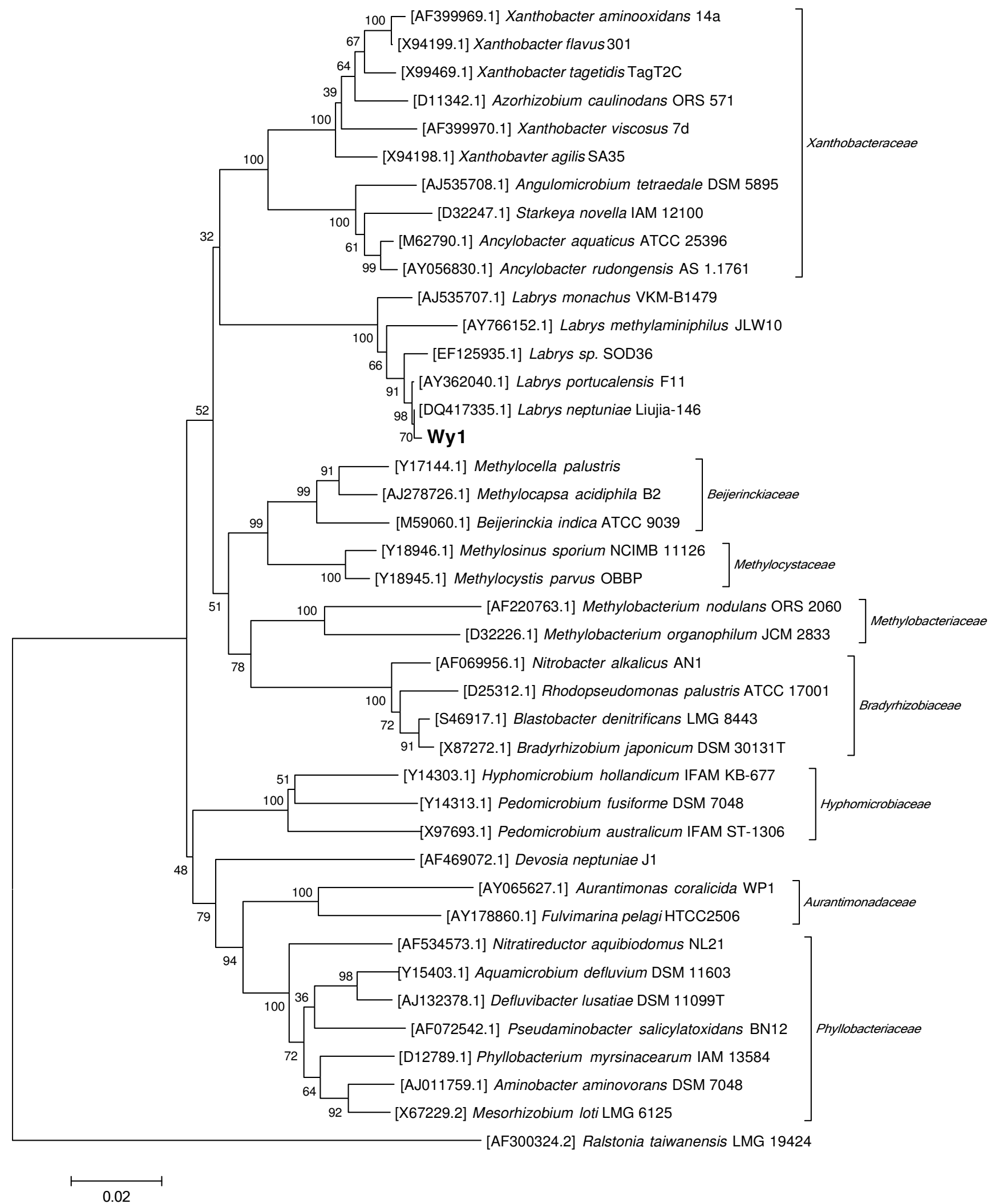

Figure 3. Phylogenetic tree of isolate $\mathrm{Wy} 1$ (Bolded) and related bacteria species (Bar: $2 \%$ dissimilarity). 
Table 3. Species of bacteria identical to Wy1 $16 \mathrm{~S}$ rRNA gene sequence.

\begin{tabular}{llccc}
\hline Accession number & Description & Maximum score & Query coverage (\%) & Maximum identity (\%) \\
\hline DQ417335.1 & Labrys neptuniae Liujia-146 & 2392 & 100 & 99 \\
AY362040.1 & Labrys portucalensis F11 & 2383 & 100 & 99 \\
EF125935.1 & Labrys sp. SOD36 & 2343 & 100 & 98 \\
EF125940.1 & Uncultured Labrys sp. clone A5 & 2334 & 100 & 98 \\
AB271044.1 & Labrys ginsengisoli & 2331 & 100 & 98 \\
EU855784.1 & Alpha proteobacterium PCNB-21 & 2287 & 95 & 99 \\
AB236172.1 & Labrys methylaminiphilus G24103 & 2280 & 98 & 98 \\
DQ337554.1 & Labrys methylaminiphilus & 2280 & 98 & 98 \\
NR025581.1 & Labrys monachus VKM B1479 & 2268 & 100 & 97 \\
AB236169.1 & Labrysokinawensis MAFF 210191 & 2248 & 98 & 97 \\
\hline
\end{tabular}

portucalensis PCNB -21 isolated from polluted soil was also found to be capable of degrading Pentachloronitrobenzene (PCNB) under aerobic and anoxic conditions ( $\mathrm{Li}$ et al., 2011). Both bacteria were able to use halogenated compound as sole source of carbon. Current study is the first reported case of the respective bacteria from genus Labrys which could degrade $\alpha$-haloalkanoic acid.

\section{ACKNOWLEDGEMENTS}

Wen-Yong Wong thanks UTM-(ZAMALAH) and Vot.Q.J130000.7135.00H34 for sponsoring this work.

\section{REFERENCES}

Allison N, Skinner AJ, Cooper RA (1982). The dehalogenases of a 2,2 dichloropropionate-degrading Bacterium. J. Gen. Microbiol., 129: 12831293.

Altschul SF, Madden TL, Schaffer AA, Zhang J, Zhang Z, Miller W, Lipman DJ (1997). Gapped BLAST and PSI-BLAST: a new generation of protein database search programs. Nucleic Acid Res., 25(17): 3389-3402.

Bergman JG, Sanik J (Jr.) (1957). Determination of trace amounts of chlorine in Naphtha. Anal. Chem., 29: 241-243.

Berry EKM, Allison N, Skinner AJ (1979). Degradation of the selective herbicide 2,2-ichloropropionate (Dalapon) by a soil bacterium. J. Gen. Microbiol., 110: 39-45.

Carvalho MF, Marco P, Duqua AP, Pacheco CC, Janssen DB, Castro PML (2008). Labrys portucalensissp. nov. a flurobenzene-degrading bacterium isolated from an industrially contaminated sediment in northern Portugal. Int. J. Sys. Evol. Microbiol., 58(3): 692-698.

Chou YJ, Elliott GN, James EK, Lin KY, Chou JH, Sheu SY, Sheu DS, Sprent JI, Chen WM (2007). Labrys neptuniae sp. nov., isolated from root nodules of the aquatic legume Neptunia oleracea. Int. J. Syst. Evol. Microbiol., 57:577-581.

Fetzner S, Lingens F (1994). Bacterial Dehalogenases: Biochemistry, Genetics, and Biotechnological Applications. Microbiol. Rev., 58(4): 641-685.

Hardman DJ, Slater JH (1981). Dehalogenases in soil bacteria. J. Gen. Microbiol., 123:117- 128.
Hareland WA, Crawford RL, Chapman PJ, Dagley S (1975). Metabolic Function and Properties of 4-Hydroxyphenyl-Acetic Acid 1 Hydroxylase from Pseudomonas acidovorans. J. Bacteriol., 121:272 285.

Janssen DB, Scheper A, Dijkhuizen L, Witholt B (1985). Degradation of halogenated aliphatic compounds by Xanthobacter autotrophicus GJ1O. App. Environ. Microbiol., 49(3): 673-677.

Jensen HL (1957).Decomposition of chlorosubstituted aliphatic acids by soil bacteria. Can. J. Microbiol., 3:151-164.

Jing NH, Huyop F (2007). Dehalogenation of chlorinated aliphatic acid by Rhodoccussp. As. Pac. J. Mol. Biol. Biotechnol., 15(3):147-151.

Jing $\mathrm{NH}$, Huyop $\mathrm{F}$ (2008). Enzymatic dehalogenation of 2,2 dichloropropionic acid by locally isolated Methylobacterium sp. HJ1. J. Biol. Sci., 8(1): 233-235.

Jing NH, Wahab RAB, Hamdan S, Huyop F (2010). Cloning and DNA sequence analysis of the haloalkanoic permease uptake gene from Rhizobium sp. RC1. Biotechnol., 9(3): 319-325

Li R, Zheng JW, Ni B, Chen K, Yang XJ, Li SP, Jiang JD (2011). Biodegradation of pentachloronitrobenzene by Labrys portucalensis pcnb-21 isolated from polluted soil. Pedosphere, 21(1): 31-36.

Magee LA, Colmer AR (1959). Decomposition of 2,2 dichloropropionicacid by soil bacteria. Can. J. Microbiol., 5: 255-260.

Mesri S, Wahab RAB, Huyop F (2009). Degradation of 3 Chloropropionic acid (3CP) by Pseudomonas sp. B6P isolated from a rice paddy field. Ann. Microbiol., 59(3): 447-451

Miller JA, Kalyuzhnaya MG, Noyes E, Lara JC, Lidstrom ME, Chistoserdova L (2005). Labrysmethylaminiphilus sp. nov., a novelfacultativelymethylotrophic bacterium from a freshwater lake sediment. Int. J. Sys. Evol. Microb., 55:1247-1253.

Motosugi K, Esaki N, Soda K (1982). Purification and properties of a new enzyme, DL-2-haloacid dehalogenase from Pseudomonas sp. J. Bacteriol., 150(2): 522-527

Penfold WJ (1913). The inhibitory selective action on bacteria of bodies related to: a contribution monochloroacetic acid to the theory of cell intoxication. J. Hyg., 13: 34-48

Prasad R, Blackman GE (1965). Studies in the physiological action of 2,2-Dichloropropionic acid III. Factors affecting the level of accumulation and mode of action. J. Exp. Bot., 16: 545-568

Redemann CT, Meikle RW (1955). The inhibition of several enzyme systems by 2,2-dichloropropionate. Arch. Biochem. Biophy., 59(1): 106112.

Schwarze R, Brokamp A, Schmidt FRJ (1997) Isolation and characterisation of dehalogenases from 2,2-dichloropropionic acid degrading soil bacterium. Curr. Microbiol., 34: 103-109.

Saitou N, Nei M (1987). The Neighbor-Joining Method: A New Method for Reconstructing Phylogenetic Trees. Mol. Bio. Evol., 4: 406-425.

Senior E, Bull AT, Slater JH (1976). Enzyme evolution in a microbial 
community growing on the herbicide Dalapon. Nature, 263(5577): 476479.

Tamura K, Dudley J, Nei M, Kumar S (2007). MEGA4: Molecular Evolutionary Genetics Analysis (MEGA) software version 4.0. Mol. Bio. Evol., 24: 1596-1599.

Weightman AJ, Weightman AL, Slater JH (1982). Stereospecificity of 2 Monochloropropionate dehalogenation by the two dehalogenases of Pseudomonas putida PP3: evidence for two different dehalogenation mechanisms. J. Gen. Microbiol., 128: 1755-1762.
Weisburg WG, Barns SM, Pelletier DA, Lane DJ (1991). 16S ribosomal DNA amplification for phylogenetic study. J. Bacteriol., 173(2): 697 703. 